\title{
A CASE OF BUPHTHALMIA WITH NORMAL UNAIDED VISION
}

\author{
BY \\ J. H. Doggakt
}

LONDON

To the rule that the degree of myopia is roughly proportional to the amount of antero-posterior elongation of the globe, buphthalmic eyes are known to form an exception, on account of three compensating factors-flattening of the cornea, flattening of the lens, and backward displacement of the lens-whose relative importance has been mathematically calculated by Parsons. ${ }^{1}$ It will be seen that, in the case to be presently described, these factors have operated to an ideal extent.

A. G., a boy, aged 10 years, has been attending as an out-patient at Moorfields for over a year, during which time it has not been possible to detect any change in the condition of his eyes. $\mathrm{He}$ has never complained of any symptoms. Both corneae have a diameter of $13.5 \mathrm{~mm}$. The tension in each eye is full normal. The visual fields, tested with a $0.5^{\circ}$ moving white object, are normal. A peculiar arrangement of vessels is seen in the right optic disc: the central retinal artery is invisible, but six arterial branches radiate from the edge of the disc. In the left eye, there is a deep physiological cup. There are no ruptures of Descemet's membrane. Each eye, unaided, sees 6/6 and J.1. When first the boy came to hospital, he was prescribed pilocarpine drops for safety's sake, but, having remained under observation for so long without developing any unfavourable signs, he will probably be allowed to stop all treatment soon.

The paternal uncle of A.G.'s mother has a son whose four children are all said to have very large, but normally functioning eyes. Unfortunately they live too far from London to be available for examination. With these exceptions, no other member of the family is known to be affected. That the condition is, like microphthalmia, prone to display a familial incidence was shown by the investigations of Kayser, ${ }^{2}$ who traced seventeen males, spread out over four generations, with enlargement of the corneal diameter up to $14.5 \mathrm{~mm}$. They were all healthy individuals, with good sight, normal tension, clear corneae, and non-pathological optic discs. Only one out of the seventeen suffered from glaucoma in later life. Kayser considers that these seventeen patients cannot correctly be called buphthalmic, and that the condition should be described as a simple enlargement of the cornea, i.e., megalocornea. In this contention he is supported by Seefelder, ${ }^{3}$ who described a similar case, and laid down a series of 
ten criteria by which to distinguish megalocornea (or megalophthalmia) from buphthalmia (or hydrophthalmia).

Treacher Collins $\mathrm{s}^{4}$ in 1913 reported the unusual phenomenon of a $1 \tau$ year old boy, who achieved normal vision in both eyes with the aid of a moderate correction for myopia; whose visual fields and optic discs were normal; and all this in spite of a corneal diameter of $14.75 \mathrm{~mm}$. in the right, $14 \mathrm{~mm}$. in the left eye. He considered the patient to be buphthalmic. Seven years later, on re-examining the eyes, and finding no evidence of any change in the condition recorded in 1913, Treacher Collins ${ }^{5}$ pointed out that the corneal enlargement obviously could not be attributed to stretching from any increase in intra-ocular tension. He expressed himself in agreement with the views which had in the meantime been put forward by Kayser ${ }^{2}$ and Seefelder ${ }^{3}$ and went on to describe still another case of what he now called megalocornea.

Whether the case I have recorded should be designated buphthalmic or megalocorneal is of no great importance, but I have preferred to use the term buphthalmia because I think it improbable that there is any sharp line of division between the two conditions. Zorab, ${ }^{6}$ in the discussion that followed Treacher Collins's paper in 1920, mentioned the case of an infant with large corneae, first seen at the age of 4 months, and remaining under observation until the age of $2-3$ years, by which time the left eye had to be excised on account of gross expansion leading to lagophthalmia, whereas the right eye had every appearance of being sound. It is easier to regard this infant as the victim of one condition affecting the two eyes with a different degree of severity than to postulate two radically different conditions arising as a coincidence in one subject. Moreover, the word buphthalmia, used in its ordinary derivative sense, does not connote glaucoma, although it happens that glaucoma is commonly associated.

I wish to express my thanks to Sir John Parsons for his kindness in allowing me to publish this case.

\section{REFERENCES}

1. Parsons, J. Herbert.-Brit. Jl. of Ophthal., Vol. IV, p. 211, 1920.

2. Kayser.-Klin. Monatsbl. f. Augenheilk., Bd. LII, No. 1. S. 226, 1914.

3. Seefelder.-Actes du XII Congrès Internat. d'Ophtal., p. 15, 1914.

4. Collins, E. Treacher.-Trans.' Ophthal, Soc. U.K., Vol. XXXIII, p. 132, 1913.

5. Trans. Ophthal. Soc. U.K., Vol. XL, p. 132, 1920.

6. Zorab, A.-Ibid. 